\title{
DANUBE AND THE FACILITATION OF NAVIGATION ON DANUBE
}

\section{Ciprian - Beniamin Benea, ${ }^{1}$ Adina Secară Oniţa ${ }^{2}$}

\begin{abstract}
With $2857 \mathrm{~km}$ in length, the quiet Danube quietly tells Europe's history. We only must be aware of its story. Since ancient times it was connected with empires, expansion, and navigation. The Romans fully understood its role, and proceeded accordingly. They made it their border, but used it for transporting goods and military, too. After the Dark Ages, all European affairs have been in one way or another connected and influenced by the Danube. Romania's modern history was influenced by the evolution of international problems connected to this river. The Moldavia and Wallachia 1859's unification in a single state - Romania - had lot to do with the Danube and it was involved in London's interests in the Oriental Question. The paper presents shortly the way the legal framework regarding the Danube was developed, and what was Romania's role in facilitating navigation on the Danube. The main data which inspired this work - regarding both the political-legal aspects, and the technical solutions used to facilitate navigation on Danube - are based on earlier writings and studies of Romanian thinkers such as Antipa, Baicoianu, Dascovici and Gogeanu. The evolution of these aspects has a direct or an indirect connection with the evolution of political events and the economic development in all European states, but their importance is crucial especially for those countries which are located in the Danube's basin. The main text regarding the political aspects related to the Danube is the Belgrade Convention, which has been the general framework under which riparian countries come together to collaborate and to solve the technical impediments for navigation, such as those imposed by the building of the Iron Gate System. At the same time, this paper signals the role of education in understanding the Danube's role for riparian countries, and for their possible evolution in connection with this river.
\end{abstract}

JEL Classification Numbers: F02; O19; R00; DOI: http://dx.doi.org/10.12955/cbup.v5.897

Keywords: education; Danube; legal means; navigation; technical means

\section{Introduction}

Danube is a river which flows from Western Europe to its Eastern part, creating a natural corridor through its middle; in fact it is the only natural route passing through the center of the European continent to its Easter region. Exactly due to its location and geographical position, it has constituted as a "battle-field" among main powers in different historical periods. They have recognized its keyposition for controlling the Danube's riparian states, and for promoting their narrow interests. But after the Enlightenment, and especially after the Crimean War in 1856, different countries started to look at the Danube in a manner which was quite different from the situation peculiar before.

This is exactly the period when Romania started to "appear" on Europe's map, with its great geopolitical potential. In fact, Romania's geopolitical position and her economic and national advances depend in a crucial manner on the free navigation on the Danube. Even her appearance on the map as a modern state was directly connected with this river. Furthermore, between 1856 and 1948 there was a period when different European states manifested their special interests regarding the Danube, especially its strategic Delta. Of course, there were general interests from their part, which went hand in hand with those of the riparian states located on the lower Danube, regarding navigation conditions.

This results in the creation of legal and technical instruments and means for this aim. But the main decision regarding technical facilitation was taken in Belgrade in 1948, when the Danube Convention was concluded by the riparian states. With this occasion, it was the first time that non-riparian states were excluded from participating in the affairs regarding the Danube. After this situation was created, the "obligation," was mentioned, for the riparian states, which had to remove all obstacles which could hinder or affect navigation of the Danube river. Synthetically, there are three different means of improving the navigation on the Danube river: one is legal, the second is technical, and the third which I consider of utmost importance - is that one which is correlated with the consciousness of the people from the riparian states, regarding the importance of the Danube for their country. Using this river's potential is connected not only to international conventions regarding navigation and transport, or technical improvements focusing on dams, locks, and ships, but to the people from the riparian states and their deep understanding of the Danube's importance for their country; and this has to do with their education.

\footnotetext{
${ }^{1}$ University of Oradea, Faculty of Economics; c_benea@yahoo.com

${ }^{2}$ University of Oradea, Faculty of Economics; ooadina@ yahoo.com
} 


\section{What the Danube means}

There is no doubt of European interest related to the Danube; and this is not new at all. Since ancient times different emperors and kings aimed at controlling this river. The great Romanian romantic writer - Mihai Eminescu - recalled in one of his best known poems, "The Third Letter," the interest on Danube for Darius, son of Histaspes. While establishing the Danube as the political border of the Roman Empire by the Roman Emperor Augustus recalls the military, cultural and political separation between the parts of Europe situated north, and respectively south, of this great waterway. In the late part of the Middle Ages the Ottoman Turks used this waterway to penetrate into Central Europe, after Moldavia lost its fortresses (Chilia and Cetatea Alba, in 1484); the great battles between the Turks and the various European powers followed the great line described by the Danube: Sabac, Belgrade, Mohacs, Budapest, and Vienna (twice) are the best witnesses in this regard. The geographical turning point in European history, when Sobieski played a key-role, was connected with Danube: the second siege of Vienna marked the beginning of the decay of Turkish power, and the ascension of Europe's power. The line marked by the Danube again became the confronting interests of those involved in this great policy.

Even the evolution of Romanian states is directly influenced by their freedom of using the Danube; with the Treaty of Adrianopole (1829) the Turkish possessions on the left bank of Danube were attached to Wallachia's territory. All these were in connection with the English interests, in this period London guarding carefully to provide for a free navigation on Danube, which until then were hindered by the Turks. In 1856, after the Crimean War, France and England being aware of Russia's interests in the Danube Delta connected to Eastern Europe approved the attachment of Bessarabia to Moldavia. Furthermore, the union between Moldavia and Wallachia was considered necessary. In order to control the Danube, there was needed for a bigger country close to its delta, ruled by a unique hand, indebt to London, and especially to Paris.

Between the two world wars a brilliant Romanian diplomat with a great vision - Nicolae Titulescu focused on the conception of interwar Romania's foreign policy connected to the Danube and the Black Sea straits.

As we can see, the importance of this river is connected to geography: it is the only big river which flows from West to East, cutting Europe through its middle. As in other situations, geography determines and compels people to adapt to it, to compete, or to collaborate in a predetermined geographical environment, which hasn't been changed. Nowadays with its 2850 kilometers, the Danube is the river which crosses the biggest number of countries in the world from its spring to its Delta, ten countries, respectively; in comparison the Nile crosses the territory of nine countries.

What is important in the present paper's context is to recall the Danube's role to promote cooperation among its riparian states.

There is a European interest connected to the freedom of navigation on the Danube. All its riparian states would benefit from its flowing waters only when navigation is free, while hindering navigation or seizing it by hidden or niggardly interests is a serious obstacle for different riparian nations' normal and legitimate aspirations. As always, history becomes the best witness in this regard; but in order to avoid unjust developments it needs to become the teacher of the Danube's riparian states' people. In this context, education and the facilitation of understanding of Danube's role for the riparian states' evolution plays, and will always play a crucial role in their destiny.

As humanity surpassed the Middle Ages there were changes, both in diplomacy and in the technical field. Humankind's history is directly connected to sciences' development, and in its evolution, humankind has always made its first leap in sciences. A discovery in this field generates deep changes in technical, social, legal, and political fields. Galileo's thesis marked this turning point in human history. It prepared the way for a new diplomacy and a new legal system.

As mentioned by Nicolson (1955), between Rome's falling (476 a.d.) and 1575 a.d., diplomacy was totally disorganized but, between 1573 and 1914 diplomacy was under the newer umbrella of "European states' system", while the third period in diplomacy's evolution has to do with "democratic diplomacy", one of its expressions being multilateral and conference diplomacy (Maliţa, 1975).

The situation regarding the Danube followed the same path: before the end of the 15-th century, the relations among the different entities related to the Danube were accidental; after that, there was 
diplomacy which facilitated the permanent maintenance of contacts among different powers involved in one way or another in the Danube's affairs.

The invention of steam engine's invention and as a consequence - the expansion of railways and steam navigation - had facilitated the appearance and consolidation of nation states, and also that of multilateral diplomacy.

The Danube, as a geographical element, started to be more and more regarded through these new angles, due to the evolution registered in both, diplomatic/legal and technical areas. The Danube was regarded as a geographical element which could facilitate the creation of a brotherhood among different nations.

The Treaty of Paris (ending the Crimean War-1856) was of outmost importance from Romania's point of view, and from the European angle too. It was this treaty which consecrated the freedom of navigation on the Danube, and as an appendix, the Black Sea's neutralization. The Danube's regime was guaranteed and put under the surveillance of Europe's interest. With this treaty, Danube's navigation entered under the European system of public law (Băicoianu, 1915). This new regime was a great opera of progress and civilization, and it was of outmost political importance and foreseeing: it provided free navigation on Danube for vessels registered under any nation's flag - a visible proclamation of promoting nations' brotherhood on international rivers.

From Romania's national point of view, it is noteworthy to mention the remark made by Carol the 1-st related to the Danube: being counseled to refuse the crown of a country without any future, he looked to Europe's map and to that of the Danube, and said that because Romania is crossed by this river, which is "the most direct line between Europe and the Indies, this country has a great role to play in the world trade" (Antipa, 1921).

The institutional mean for promoting freedom of navigation was Danube's European Commission. It promoted and provided surveillance for free navigation and the identification of all technical obstacles hindering navigation, especially between Isaccea and Black Sea.

For the Romanian nation, the Danube guarantees its future and its development in the great competition among different nations, and as a consequence, the Danube dictates Romania's special interests and its policy. The manner Romania understands how to play its role in the Danube Delta and Iron Gate System areas crucially influences the Romanians' destiny among other nations in the world.

Romania has the greatest interest in free and unhindered navigation on the Danube, and this interest is the same with that of all other Danube riparian states. Daşcovici said (1936) that Romania depends in such a measure on Danube's navigation that Romania's "future, as well as her past", is influenced in such a way that this old Danube has been "the force of protection, renaissance, and then of Romanian nation's consolidation, as well as European interests related to free navigation on it, which coincided with" Romania's "best understood interests".

Anyway, it was only after 1948 when Romania started to play a decisive role in the Danube's affairs. Even if it had been "allocated" to the communist block after the WW II, it would have been only then that all powers with no territory connected directly to Danube were excluded from the "administration" of this river. There were only left the riparian states with the right to collaborate in order to provide smoother navigation (from a technical point of view) and free navigation (from a legal point of view). For promoting this aim, the Danube's Commission was created (its first headquarter was in Galatzi, then it was changed to Budapest, where it is still today).

It was at Belgrade in August 1948 that a Convention was concluded with a huge political impact upon the Danube's riparian states, as Gogeanu mentioned (1970); this convention facilitated cooperation among Danube's riparian states, facilitating the removal of obstacles for navigation, but eliminated non-riparian states from these processes. The Danube riparian states' sovereignty was consolidated in connection with the general interests connected to free navigation, while the special administrations of peculiar areas were to be provided under a special status, by the riparian states with direct access to those areas. There were created the Special River Administration for the Lower Danube (having at its base the bilateral agreement between USSR/Ukraine and Romania) and the Special Administration of the Iron Gates (having at its base the bilateral agreement between Romania and Yugoslavia/Serbia), both of them being in relation with Danube's Commission in Budapest. 
These were the legal and administrative means for promoting cooperation among Danube's riparian states aiming at the facilitation of navigation, bringing benefits to them all. Where the Danube marks the border between two states, the rules of navigation were to be established by those peculiar states, and not by the Commission of Danube, giving a new meaning and significance to national sovereignty, and to the general interests connected to free navigation on the Danube. The Commission of Danube has had a very high utility for riparian states, for it created the institutional forum which facilitated the continuous coordination of activities which have promoted the expanded collaboration among Danube riparian states' economies and societies (Gogeanu, 1970).

From a technical point of view, there were identified two areas of outmost importance: the Danube Delta, and the Iron Gate sector. There were established legal means for countries neighboring these two areas, and their obligation to remove all obstacles for navigation on this international waterway (art. 20, Convention of Belgrade, 1948).

One special area where permanent dragging is needed concerns Sulina's arm of the Danube. The special bilateral institution aims at managing this part of the Danube in a sustainable and continuous manner this aspect. Furthermore, between kilometer 1821-1791 (between Gabcikovo and Gonyu) there is a permanent changing of river bed and water depth.

The greatest obstacles for navigation were to be found in the Iron Gate sector, where the shallow water coupled with a high water speed, created the most dangerous conditions for navigation on the whole Danube. These obstacles were technical hindrances between the lower part of the Danube and the countries situated on its middle and superior course. Even starting in 1838 some Germans, Austrians, and Hungarians tried to resolve these impediments, but missing technical means, coupled with some narrow interests, their solutions were not effective. In 1895 Hungary received the right to work in this sector in order to remove the obstacles for navigation, but, even after four years of steady work, the aim was far from being definitively achieved. Cutting a canal of 2840 meters, while refusing to adopt the technical solution with locks, as mentioned by Băicoianu (1915), rose the water's speed to 3-5 m/s, and with all these efforts, the difficulties for navigation were still complex. The navigation in the Iron Gate sector had remained dangerous, and more expansive than in the past.

The technical solution which proved to be the best was the locks system. What is important to mention here is that the Iron Gate System was created under the stimulus and umbrella of the Convention of Belgrade, but it was the direct result of Romanian and Yugoslavian effort. In fact, the technical solution of the Iron Gate System has two interconnected principles and parts: facilitating cooperation among riparian states through improving the navigation conditions, and using the water's potential to generate electricity by two neighbouring and friend countries. This solution was the best, it combined the general interests of navigation with the special interests of Romania and Yugoslavia related to energy production (and independence in this strategic field).

\section{What should the Danube mean for Romanians}

Tacking account of these historical, political and technical realities, we must never forget that free navigation on Danube represents a key-stone of Romania's domestic and foreign policy.

Now, to utilize the Danube's potential, something must be done more than just connecting things to international law and the general interests of all riparian states; the technical and human means for navigation must be created. Ships, personal, technical facilities in ports, and shipping companies are of outmost importance in this context. Under this view point, shipping companies (even if they are private) are geopolitical instruments used for promoting national interests. Even if a riparian country had excelled in international cooperation facilitating the navigation on the Danube, missing its national flag on this river's waters, and beyond it, is not only a sign of technical incapacity, but of political weakness, and administrative impotence. States rise as their transport means evolve, while the decay of the states is first encountered in the transportation area.

That for, Romanians must be aware of the role Danube plays in Romania's destiny; history is a very good teacher in this regard. Becoming familiar with the Danube's influence upon Europe, the role Romania could play in this river basin could be well improved. Educating Romanian pupils having this in mind will bring benefits in the future for all the Danube's riparian states. Without understanding this, Romanians could very carefully guard other states' interests on the Danube, but they still miss the capacity to benefit from this river great potential fully. 
As we can synthetically note, for Romania, there are already legal means which sustain transport on the Danube, technical means which removed the impediments in the most dangerous areas of the river, the Iron Gate, but the cultural, educational, and technical elements which could make Danube the most important corridor for transporting Romania's goods are missing.

Put in another way, Romania is very open when it comes to international collaboration and the rule of law, but when it is about Romania's destiny and guarding its national interests, it is a national disappointment.

The Danube remains a river with an ideal potential, far away from daily realities.

\section{Conclusion}

As was stated above, it is important to note the peculiar role Danube has played in the history of Europe. This should be the focus of present generation, and through education, of future generations too. This river is the quiet witness of how geographical elements and peculiarities have been used by different powers of the moment, to promote their narrow interests to the detriment of others. While the changing context after the 2nd World War, with promoting regional integration, totally reoriented the way Europeans see the Danube. The European integration process cannot be imagined without the Danube as its main artery of trade. The Danube becomes the natural pathway for political integration and cooperation among all its riparian countries and among them and other countries which this river indirectly connects, from the Middle East and Central Asia to the Rhine's riparian countries. In Romania's particular case, it is necessary for all Romanians to understand the Danube's role in their history, in order to transform the Danube's potential into real life benefits.

\section{References}

Antipa, G. (1921). Dunărea şi problemele ei ştiinţifice, economice şi politice. Bucureşti: Librăriile $<<$ Cartea Românească $>>$ şi Pavel Suru.

Băicoianu, C. I. (1915). Dunărea. Privire istorică, economică şi politică. Bucureşti: Tipografia „Eminescu”. Convention of Belgrade (1948).

Daşcovici, N. (1936). Dunărea noastră. Bucureşti: Fundaţia Culturală „Principele Carol”.

Gogeanu, P.(1970). Dunărea în relaţiile internaţionale. Bucureşti: Editura Politică.

Iorga, N. (1985). Locul românilor în istoria universală. Bucureşti: Editura Ştiinţifică şi Enciclopedică.

Maliţa, M. (1975). Diplomaţia. Şcoli şi instituţii. Bucureşti: Editura Didactică şi Pedagogică.

Nicolson, H. (1955). Diplomacy. London: Oxford University Press. 